\title{
Communication
}

\section{Proteomic Shifts Reflecting Oxidative Stress and Reduced Capacity for Protein Synthesis, and Alterations to Mitochondrial Membranes in Neurospora crassa Lacking VDAC}

\author{
Sabbir R. Shuvo ${ }^{1,2}{ }^{\infty}$, Anna Motnenko ${ }^{2}$, Oleg V. Krokhin ${ }^{3,4}$, Victor Spicer ${ }^{4}$ and Deborah A. Court ${ }^{2, *(1)}$ \\ 1 Department of Biochemistry and Microbiology, North South University, Dhaka 1229, Bangladesh; \\ Sabbir.Shuvo@northsouth.edu \\ 2 Department of Microbiology, University of Manitoba, Winnipeg, MB R3T 2N2, Canada; \\ Anna.Motnenko@umanitoba.ca \\ 3 Department of Internal Medicine, University of Manitoba, Winnipeg, MB R3T 2N2, Canada; \\ Oleg.Krokhine@umanitoba.ca \\ 4 Manitoba Centre for Proteomics and Systems Biology, Winnipeg, MB R3E 3P4, Canada; \\ Victor.Spicer@umanitoba.ca \\ * Correspondence: Deborah.Court@umanitoba.ca; Tel.: +1-(204)-474-8263
}

Citation: Shuvo, S.R.; Motnenko, A.; Krokhin, O.V.; Spicer, V.; Court, D.A. Proteomic Shifts Reflecting Oxidative Stress and Reduced Capacity for Protein Synthesis, and Alterations to Mitochondrial Membranes in Neurospora crassa Lacking VDAC. Microorganisms 2022, 10, 198. https://doi.org/10.3390/ microorganisms10020198

Academic Editor: Tassos Economou

Received: 30 November 2021

Accepted: 13 January 2022

Published: 18 January 2022

Publisher's Note: MDPI stays neutral with regard to jurisdictional claims in published maps and institutional affiliations.

Copyright: (c) 2022 by the authors. Licensee MDPI, Basel, Switzerland. This article is an open access article distributed under the terms and conditions of the Creative Commons Attribution (CC BY) license (https:// creativecommons.org/licenses/by/ $4.0 /)$.

\begin{abstract}
Voltage-dependent anion-selective channels (VDAC) maintain the bidirectional flow of small metabolites across the mitochondrial outer membrane and participate in the regulation of multiple cellular processes. To understand the roles of VDAC in cellular homeostasis, preliminary proteomic analyses of S100 cytosolic and mitochondria-enriched fractions from a VDAC-less Neurospora crassa strain ( $\triangle$ Por- 1 ) were performed. In the variant cells, less abundant proteins include subunits of translation initiation factor eIF-2, enzymes in the shikimate pathway leading to precursors of aromatic amino acids, and enzymes involved in sulfate assimilation and in the synthesis of methionine, cysteine, alanine, serine, and threonine. In contrast, some of the more abundant proteins are involved in electron flow, such as the $\alpha$ subunit of the electron transfer flavoprotein and lactate dehydrogenase, which is involved in one pathway leading to pyruvate synthesis. Increased levels of catalase and catalase activity support predicted increased levels of oxidative stress in $\Delta$ Por- 1 cells, and higher levels of protein disulfide isomerase suggest activation of the unfolded protein response in the endoplasmic reticulum. $\Delta$ Por- 1 cells are cold-sensitive, which led us to investigate the impact of the absence of VDAC on several mitochondrial membrane characteristics. Mitochondrial membranes in $\Delta$ Por- 1 are more fluid than those of wild-type cells, the ratio of C18:1 to C18:3n3 acyl chains is reduced, and ergosterol levels are lower. In summary, these initial results indicate that VDAC-less N. crassa cells are characterized by a lower abundance of proteins involved in amino acid and protein synthesis and by increases in some associated with pyruvate metabolism and stress responses. Membrane lipids and hyphal morphology are also impacted by the absence of VDAC.
\end{abstract}

Keywords: VDAC; Neurospora crassa; mitochondria; cytosol; proteomics; unfolded protein response; oxidative stress; ergosterol; hyphae; shikimate; amino acid biosynthesis

\section{Introduction}

The mitochondrial outer membrane (MOM) harbours mitochondrial porins, also known as voltage-dependent anion-selective channels (VDAC). These proteins are composed of $19 \beta$-strands and an N-terminal $\alpha$-helix [1-4] and form aqueous channels linking the intermembrane space and the cytosol [5]. In artificial membranes, the open conformation of VDAC is slightly anion-selective and a voltage-induced, partially closed confirmation is slightly cation-selective [6,7]. The N-terminus of VDAC is proposed to participate in the gating of VDAC between these two states [8-10]. Neurospora crassa is a useful model organism for the investigation of the functions of VDAC, as a single VDAC isoform is 
present [11]. The strain of N. crassa lacking VDAC ( $\triangle$ Por-1) is viable but cold-sensitive and slow-growing, and it displays electron transport chain (ETC) defects and expresses alternative oxidase [12]. These changes are associated with increased potential for the production of reactive oxygen species (ROS) [13]. Thus, the absence of VDAC is associated with altered mitochondrial function and may be accompanied by stress responses.

Previously, iTRAQ [12] and one-dimensional liquid chromatography followed by tandem mass spectroscopy (1D LC-MS/MS) [14] were used to analyze the proteome of VDAC-less $N$. crassa mitochondria. A small number of proteins (Table 1) were identified as being over- or under-represented in the $\Delta$ Por- 1 strain in these studies. In general, proteins involved in energy production, mitochondrial amino acid metabolism, and transport were more abundant; in contrast, some NADH-ubiquinone oxidoreductase (complex I) subunits were less abundant [14]. Although the same strains were used in both studies, some of the intermembrane space proteins that were relatively low in the iTRAQ experiments [12] had similar relative levels as those in the wild-type (WT) in the 1D LC-MS/MS study [14]. The flotation gradient step used to purify mitochondria more highly in the iTRAQ study might have caused additional disruption of the MOM in the VDAC-less strain, leading to under-representation of proteins from that compartment [14].

Table 1. Summary of $\Delta$ Por-1 proteomic studies.

\begin{tabular}{ccccc}
\hline $\begin{array}{c}\text { Source of Sample } \\
\text { (Method) }\end{array}$ & $\begin{array}{c}\text { Proteins } \\
\text { Detected }\end{array}$ & $\begin{array}{c}\text { Proteins More } \\
\text { Abundant in } \\
\Delta \text { Por-1 }\end{array}$ & $\begin{array}{c}\text { Proteins Less } \\
\text { Abundant } \\
\mathbf{\Delta P o r}^{2} \mathbf{2}^{2}\end{array}$ & Reference \\
\hline $\begin{array}{c}\text { S100 cytosol-enriched } \\
\left.\text { (1D LC-MS/MS }{ }^{1}\right)\end{array}$ & 1031 & 74 & 96 & This work \\
\hline $\begin{array}{c}\text { Mitochondria-enriched } \\
\text { (2D LC-MS/MS) }\end{array}$ & $867^{3}$ & 23 & 37 & This work \\
\hline $\begin{array}{c}\text { Mitochondria-enriched } \\
\text { (1D LC-MS/MS) }\end{array}$ & 542 & 10 & 13 & [14] \\
\hline $\begin{array}{c}\text { Mitochondria-enriched } \\
\text { (iTRAQ) }\end{array}$ & 489 & 12 & 7 & [12] \\
\hline
\end{tabular}

${ }^{1} \mathrm{D}$, dimensional; LC, liquid chromatography; MS, mass spectroscopy; ${ }^{2} p<0.05 ;{ }^{3}$ mitochondrial proteins were identified using the method described in [14].

The impacts on other non-mitochondrial compartments and biochemical pathways were not examined in the previous studies of samples enriched for mitochondria. In the current study, the proteomic profiles of S100 fractions enriched in cytosolic proteins were examined and complemented with a preliminary, but deeper, 2D LC-MS/MS proteomic analysis of mitochondria-enriched samples to further enhance our understanding of the protein expression profile of the VDAC knockout $N$. crassa cells. The stress responses implicated by these data were examined in vivo. Finally, analyses of the acyl chains of membrane lipids and ergosterol were carried out to investigate the contributors to the cold sensitivity of the $\Delta$ Por-1 strain.

\section{Materials and Methods}

\subsection{Chemicals}

Unless otherwise mentioned, chemicals were obtained from Thermo Fisher Scientific (Mississauga, ON, Canada), Sigma-Aldrich Canada (Oakville, ON, Canada) or BioShop Canada (Burlington, ON, Canada). 


\subsection{N. crassa Strains and Growth Conditions}

N. crassa strains FGSC 9718 (WT, $\Delta m u s-5::$ bar mat $a ;[15,16]$ and $\Delta$ Por-1 $\left(\Delta p o r:: h p h^{+}\right.$ $\Delta$ mus51::bar ${ }^{+}$transformant of FGSC 9718) [12] were used in this study. Growth and handling of the N. crassa strains were performed following the procedures described in [17] at $30^{\circ} \mathrm{C}$.

\subsection{Proteomic Analysis of Enriched Mitochondrial and S100 Cytosolic Fractions}

Mitochondria were enriched from $N$. crassa cell extracts by following the differential centrifugation protocol described in $[18,19]$. To avoid damage to the membranes, mitochondria were prepared without a flotation gradient step. Samples were prepared for proteomic analysis as described in [20]. In brief, mitochondria-enriched samples were lysed with sodium dodecyl sulfate (SDS) and subsequently washed with urea buffer to remove SDS. Proteins were digested with trypsin (50:1 $(w / w))$ and then acidified using trifluoroacetic acid (final concentration $0.5 \%$ ) and desalted using a $1 \times 100 \mathrm{~mm}$ column packed with $5 \mu \mathrm{m}$ of Luna C18(2) (Phenomenex, Torrance, CA, USA). Purified peptide mixtures were lyophilized and subjected to 2D liquid chromatography (LC) and tandem mass spectroscopy (MS/MS) following the method of [21].

Mass spectrometric (MS) acquisition was performed using an ABSciexTripleTOF 5600 TOF-MS system (Applied Biosystems, Foster City, CA, USA) equipped with a NanosprayIII ionization source. Each acquisition cycle included a $250 \mathrm{~ms}$ survey, MS acquisition $(\mathrm{m} / z$ 400-1500) and up to twenty $100 \mathrm{~ms}$ MS/MS measurements on the most intense parent ions (300 counts/s threshold, +2 to +4 charge state, $m / z$ 100-1500 mass range for MS/MS). The numbers of MS/MS ions and peptides are listed in Table S1.

For isolating samples enriched in cytosolic proteins (S100), N. crassa cells were grown to exponential phase, and hyphae were harvested by filtration. Cells were ground with $1 \mathrm{~g}$ of sand in $1.5 \mathrm{~mL}$ of SEM buffer ( $250 \mathrm{mM}$ of sucrose, $1 \mathrm{mM}$ of EDTA, $9 \mathrm{mM}$ of MOPS (3-[N-Morpholino]-propanesulfonic acid), pH 7.5) containing $1 \mathrm{mM}$ of PMSF (phenylmethylsulfonyl fluoride) per $1 \mathrm{~g}$ of hyphae. Samples were then spun at $1900 \times g$ for $5 \mathrm{~min}$ in an SS34 rotor (Sorvall RC 6 Plus, ThermoFisher Scientific, Burlington, ON, Canada) to remove the cell debris and sand. Supernatants were collected and further clarified by spinning at 100,000 $\times g$ (Beckman Coulter, Optima ${ }^{\mathrm{TM}}$ Max-E Ultracentrifuge in a TLA100.3 rotor, (Beckman Coulter, LP, Mississauga, ON, Canada) for 45 min at $4{ }^{\circ} \mathrm{C}$. This S100 fraction was enriched in soluble proteins, protein complexes, and ribosomes [22], and likely, due to rupture of organelles during isolation, contained some proteins from mitochondria, the endoplasmic reticulum and Golgi, and plasma membrane (see Table S2).

For sample preparation for mass spectrometry the following protocol was used [23]. The soluble proteins were reduced $\left(10 \mathrm{mM}\right.$ of dithiothreitol, $\left.30 \mathrm{~min}, 57^{\circ} \mathrm{C}\right)$, alkylated (50 mM iodoacetamide, $30 \mathrm{~min}$ in the dark at room temperature), and dialyzed against $100 \mathrm{mM}$ of $\mathrm{NH}_{4} \mathrm{HCO}_{3}$ for $6 \mathrm{~h}$. Then, samples were digested overnight with modified trypsin (Promega, Madison, WI, USA) with a 1:100 $(w / w)$ ratio of enzyme to substrate for $12 \mathrm{~h}$ at $37^{\circ} \mathrm{C}$. The resulting tryptic digests were acidified with trifluoroacetic acid (TFA) and purified by reversed-phase solid phase extraction. Approximately $50 \mu \mathrm{g}$ of each digest, as determined by NanoDrop 2000 (ThermoFisher Scientific), was sufficient for each LC-MS experiment [21].

One-dimensional LC-MS/MS analyses were performed for $3 \mathrm{~h}$ of acquisition time for each sample. A splitless nano-flow 2D LC Ultra system (Eksigent, Dublin, CA, USA) was used to deliver water-acetonitrile gradient at $500 \mathrm{~nL} / \mathrm{min}$ flow rate through a $100 \mu \mathrm{m} \times 200 \mathrm{~mm}$ analytical column packed with $3 \mu \mathrm{m}$ of Luna C18(2) (Phenomenex, Torrance, CA, USA) at room temperature. Samples were injected $(\sim 1 \mu \mathrm{g}$ of peptides in $10 \mu \mathrm{L}$ of buffer A (water)) via a $300 \mu \mathrm{m} \times 5 \mathrm{~mm}$ PepMap100 trap-column (ThermoFisher Scientific). The gradient program included the following steps: linear increase from 0.5 to $35 \%$ of buffer B (acetonitrile) in $168 \mathrm{~min}$ followed by 5 min column wash with $90 \%$ buffer B and $7 \mathrm{~min}$ system equilibration using starting conditions of $0.5 \%$ buffer B. Both eluents $\mathrm{A}$ (water) and $\mathrm{B}$ (acetonitrile) contained $0.1 \%$ formic acid as the ion-pairing modifier. 
Data-dependent acquisition with a TripleTOF5600 mass spectrometer (ABSciex, Framingham, MA USA) was performed using following settings: $250 \mathrm{~ms}$ survey MS spectra ( $m$ / z 375-1500), which was followed by up to $20 \mathrm{MS} / \mathrm{MS}$ measurements on the most intense parent ions (300 counts $/ \mathrm{sec}$ threshold, +2 to +4 charge state, $m / z 100-1500$ mass range for MS/MS, $100 \mathrm{~ms}$ each, high sensitivity mode). Previously targeted parent ions were excluded from repetitive MS/MS acquisition for 12 s (50 mDa mass tolerance). See Table S1 for a summary of the data acquired.

For both data sets, the resulting raw WIFF files were processed using a standard conversion script, bundled with Analyst QS 1.6 (ABSciex) into Mascot Generic File format (MGF). MGF files contain information on charge, $m / z$, retention time of fragmented peptide as well as $m / z$ values and intensities of fragment ions. Mass measurements for the parent and daughter ions were used for peptide identification, while intensities of the daughter ions were used for quantitation. Spectra (in MGF format) and an overall log2 protein expression matrix are available at the University of California, San Diego, in the MassIVE archive (massive.ucsd.edu) under the accession number MSV000088567.

An in-house GPU-based peptide identification engine [24] was used for protein identification, with the following search parameters: 20 ppm and 0.1 Da mass tolerance on the parent and fragment mass, respectively, and fixed modification of cysteine residues $+57.021 \mathrm{Da}$ (cysteine protection with iodoacetamide). Only tryptic peptides with expectation values of $\log (\mathrm{e})<-1.5$ and with up to one permitted missed cleavage were used for identification. Sequence data were obtained from the 7th annotated version of the N. crassa genome, obtained from the Neurospora crassa Sequencing Project, Broad Institute of Harvard and MIT (http: / / www.broadinstitute.org/, accessed on 11 February 2016).

Protein total ion counts (TIC) were used as a relative measure of protein expression within an experimental run; these values represent the sum of the MS/MS fragment ion intensities for every identified member peptide. This value is expressed in a $\log _{2}$ scale. A single dataset was available for the mitochondria-enriched samples, which was analyzed following the methods described in [14]. These results are therefore preliminary. In short, for each protein identified in both the wild-type and mutant mitochondria, $\log _{2}$ difference values were determined and normalized to generate a mean near zero and standard deviation near one. $z$-Scores were calculated, and a minimum of $95 \%$ confidence interval was used to identify proteins differentially expressed in the two strains $(-1.96>\mathrm{z}>1.96$, Table S3 [25]).

For cytosol-enriched S100 proteins, two samples were evaluated per strain (see Table S1 for scatter plots), and the relative abundance of each protein was calculated as described in $[26,27]$. In brief, the differences between the relative abundances (TIC) for replicates from the same strain $(R 0, R 1)$ and between strains $(Z 0, Z 1)$ were calculated. These populations of difference values were normalized to generate an average of 0 , and the normalized populations were used to determine Wstat as a measure of the signal-to-noise ratio (S/N). A S/N value of 2.8 was chosen as the cut-off for significance and represents $p<0.05$ [27]. The average TIC of the proteins within this group had a difference of at least two-fold $\left(-1>\log _{2}>1\right)$ between wild-type and mutant samples and was used for the current analysis (Table S4).

To estimate the contributions of non-cytosolic proteins to the S100 fraction, the list of 1037 proteins detected in both strains was compared to the list of putative mitochondrial proteins [14] and lists of N. crassa proteins obtained from UniProt, using the search parameters Neurospora crassa and 23-OR23-1a (the standard lab strain) as well as one of the following terms: "endoplasmic reticulum", "Golgi", "endoplasmic reticulum" or "lysosome". We added a Supplementary Table (Table S2) that describes these data and presents the lists of sequences in all categories. Overall, this analysis showed 232 predicted mitochondrial proteins, 58 ribosomal proteins, 23 ER proteins, and 12 Golgi proteins, all detected in the S100 fraction of both strains. 


\subsection{Stress Analysis}

To determine the sensitivity of the cells to tunicamycin, growth rates of the cells were measured in race tubes containing Vogel's medium (VM) [17] in the presence of $2 \mu \mathrm{g} / \mathrm{mL}$ of tunicamycin [28], which induces a mild unfolded protein response in the endoplasmic reticulum of N. crassa [29].

Intracellular reactive oxygen species were measured following the protocol described in [30], with slight modifications. Cells were grown to exponential phase in $25 \mathrm{~mL}$ of VM at $30^{\circ} \mathrm{C}$ and then incubated in $15 \mu \mathrm{m}$ of $2^{\prime}, 7^{\prime}$-dichlorofluorescein (DCF) for $1 \mathrm{~h}$. Cells were washed with $100 \mathrm{~mL}$ of water and then ground in liquid nitrogen with a mortar and pestle. A total of $15-25 \mathrm{mg}$ of cell material was resuspended in $1 \mathrm{~mL}$ of phosphate buffer $(10 \mathrm{mM}$ of $\mathrm{Na}_{2} \mathrm{HPO}_{4}, 1.8 \mathrm{mM}$ of $\mathrm{KH}_{2} \mathrm{PO}_{4}, 137 \mathrm{mM}$ of $\mathrm{NaCl}, 2.7 \mathrm{mM}$ of $\left.\mathrm{KCl}, \mathrm{pH} 7.4\right)$. The solution was diluted by five-fold in the same buffer, and fluorescence was measured at an excitation wavelength of 490 and an emission wavelength of 524 in a SpectraMax Plus 384 Microplate Reader (Molecular Devices Sunnyvale, CA, USA) and normalized to the mass of protein.

Catalase activity was determined by following the process, as described in [31], with slight modification. Hyphae of N. crassa were broken with a mortar and pestle as was performed for mitochondrial preparation (above). All centrifugation steps were conducted at $4{ }^{\circ} \mathrm{C}$. Cellular debris and sand were removed by centrifugation at $1900 \times g$ at $4{ }^{\circ} \mathrm{C}$ for $5 \mathrm{~min}$. The supernatant was collected, and mitochondria were pelleted by centrifugation at $17,200 \times g$ for $12 \mathrm{~min}$. The pellet was resuspended in SEMP, and centrifugation was repeated for $20 \mathrm{~min}$. Catalase activity was measured in a Gilson oxygraph equipped with Clark electrode. One unit of catalase is defined as the amount that decomposes $1 \mu$ mole of $\mathrm{H}_{2} \mathrm{O}_{2}$ in $1 \mathrm{~min}$ in a $60 \mathrm{mM}$ of $\mathrm{H}_{2} \mathrm{O}_{2}$ solution at $\mathrm{pH} 7.0$ [32].

\subsection{Fatty Acid Analysis}

Whole-mitochondrial lipid analysis was performed following the protocol described in [33], with slight modifications. Fatty acids were extracted from mitochondria (3 $\mathrm{mg}$ of protein) in $2 \mathrm{~mL}$ of $15 \%$ concentrated methanolic sulphuric acid and $2 \mathrm{~mL}$ of chloroform. An internal standard of C17:1 was used (Nu-Chek Prep Inc., Elysian, MN, USA) in the chloroform for quantification. Samples were heated at $90^{\circ} \mathrm{C}$ for $3 \mathrm{~h}$, and $1 \mathrm{~mL}$ of deionized water was used to separate the organic phase. The percentage of each acyl chain was calculated relative to the total peak area and correlated to the internal standard.

\subsection{Sterol Analysis}

Sterol analysis was based on the protocol described in [34]. Mitochondria (3 $\mathrm{mg}$ of protein) were heated in $3 \mathrm{~mL}$ of $10 \%$ methanolic $\mathrm{KOH}$ at $80^{\circ} \mathrm{C}$ for $90 \mathrm{~min}$. After cooling, $5 \alpha$-cholestanol $(250 \mathrm{ng}$ ) was added as an internal standard followed by $1 \mathrm{~mL}$ of water. Then, $3 \mathrm{~mL}$ of hexane was added and mixed with the solution, and $1 \mathrm{~mL}$ of the organic layer was collected and used for analysis by gas chromatography [35]. The area under the curve representing ergosterol was normalized to that from the internal standard, and the normalized values for sterol from the wild-type and $\Delta$ Por- 1 strain were compared.

\subsection{Fluidity Analysis}

Mitochondrial fluidity was measured following with slight modifications of the protocol described in [36]. Mitochondria (100 $\mu \mathrm{g}$ of protein) were incubated in $2 \mathrm{~mL}$ of SEM buffer with $40 \mu \mathrm{L}$ of $1 \mathrm{mM}$ Laurdan (6-Dodecanoyl-2-dimethylamino-naphthalene, dissolved in dimethyl sulfoxide) in a Varian Eclipse spectrofluorometer (Varian Canada Inc., Mississauga, ON, Canada) at $15-58{ }^{\circ} \mathrm{C}$. The excitation wavelength was $350 \mathrm{~nm}$ and emission $(\mathrm{F})$ wavelengths were 440 and $490 \mathrm{~nm}$; the ratio of F440/F490 was used as a relative indication of fluidity [36]. 


\section{Results and Discussion}

To further enhance the understanding of the global responses associated with the absence of VDAC in N. crassa, preliminary proteomic analyses of samples enriched in mitochondria, and fractions enriched in cytosolic proteins by centrifugation of cell lysates at $100,000 \times g$, were carried out. Two strains were used: $\Delta$ Por-1, lacking VDAC [12] and the strain it is derived from, FGSC 9718 (WT). In the S100 sample, 1031 proteins were detected in both strains and of these, 232 were mitochondrial, 58 were ribosomal, 23 were associated with the endoplasmic reticulum, 12 with the Golgi, and 7 with the plasma membrane. No lysosomal proteins were detected (Table S2). This entire group of proteins was analysed, as the goal was to identify differences between the strains, rather than to explicitly examine individual cellular compartments or subfractions. A total of 170 of the 1031 proteins were differentially expressed in $\Delta$ Por-1 (Table S4). In the sample enriched for mitochondria, peptides from 2499 proteins were detected; of these 867 are known to be or predicted to be in mitochondria (Table S2; see [14]). A total of 60 of the mitochondrial proteins were differentially expressed (Table S3). This increased the depth of the data obtained in previous experiments (Table 1). The data from the current mitochondria-enriched and S100 cytosol-enriched samples were combined for analysis of pathways impacted by the lack of VDAC and are discussed together.

\subsection{Less Abundant Proteins in $\Delta$ Por-1}

A total of 133 proteins were less abundant in $\Delta$ Por- 1 cells than in WT cells (Table 1). Four main categories in the functional categorization (FunCat, FC) system [37] were represented: protein synthesis (FC 12), proteins with binding function or cofactor requirement (FC 16), energy (FC 02), and metabolism (FC 01) (Figure 1 and Table S5).

The low levels of proteins involved in translation (FC 12.04) and ribosomes (FC 12.01.01; see Table S5A) likely relate to the relatively slow growth rate of $\Delta$ Por-1 cells [12] and reduced demand for protein synthesis. Levels of individual mitochondrial and cytosolic ribosomal subunits were not uniformly reduced, but interestingly, the $\alpha, \beta$ and $\gamma$ subunits of the eukaryotic initiation factor eIF-2 were all present in significantly lower amounts in $\Delta$ Por-1, suggesting reduced initiation on cytoplasmic ribosomes. This observation is intriguing, as the down-regulation of eIF-2 activity usually occurs via phosphorylation of eIF2- $\alpha$, thereby preventing GDP-GTP exchange (reviewed in [38]).

Several pathways with significant coverage were explored further, with the understanding that protein levels are only one mechanism for controlling metabolism. In parallel to changes potentially impacting translation, proteins catalysing steps in amino acid synthesis are reduced in $\Delta$ por-1 (Table S5B; Figure 1), and this group includes enzymes involved in sulfate assimilation (01.02.03.04) and several enzymes that use pyridoxal phosphate as a cofactor (16.21.17; Table S5E). Notably, the shikimate pathway leading to chorismate, a precursor of tryptophan, tyrosine, and phenylalanine, was affected (Figure 2a), as were several enzymes linked to sulfate assimilation, sulfur amino acid synthesis (methionine and cysteine), and serine, glycine, and threonine synthesis (Figure 2b). This resembles general amino acid control (referred to as cross-pathway control (CRC) in N. crassa) [39,40]. However, CRC is achieved via phosphorylation of eIF $2 \alpha$, thereby enhancing translation of the upstream open reading frame (uORF)-containing mRNA for the transcription factor, CPC-1 [41], whereas a deficit in all eIF2 subunits may suggest a global decrease in translational initiation. 

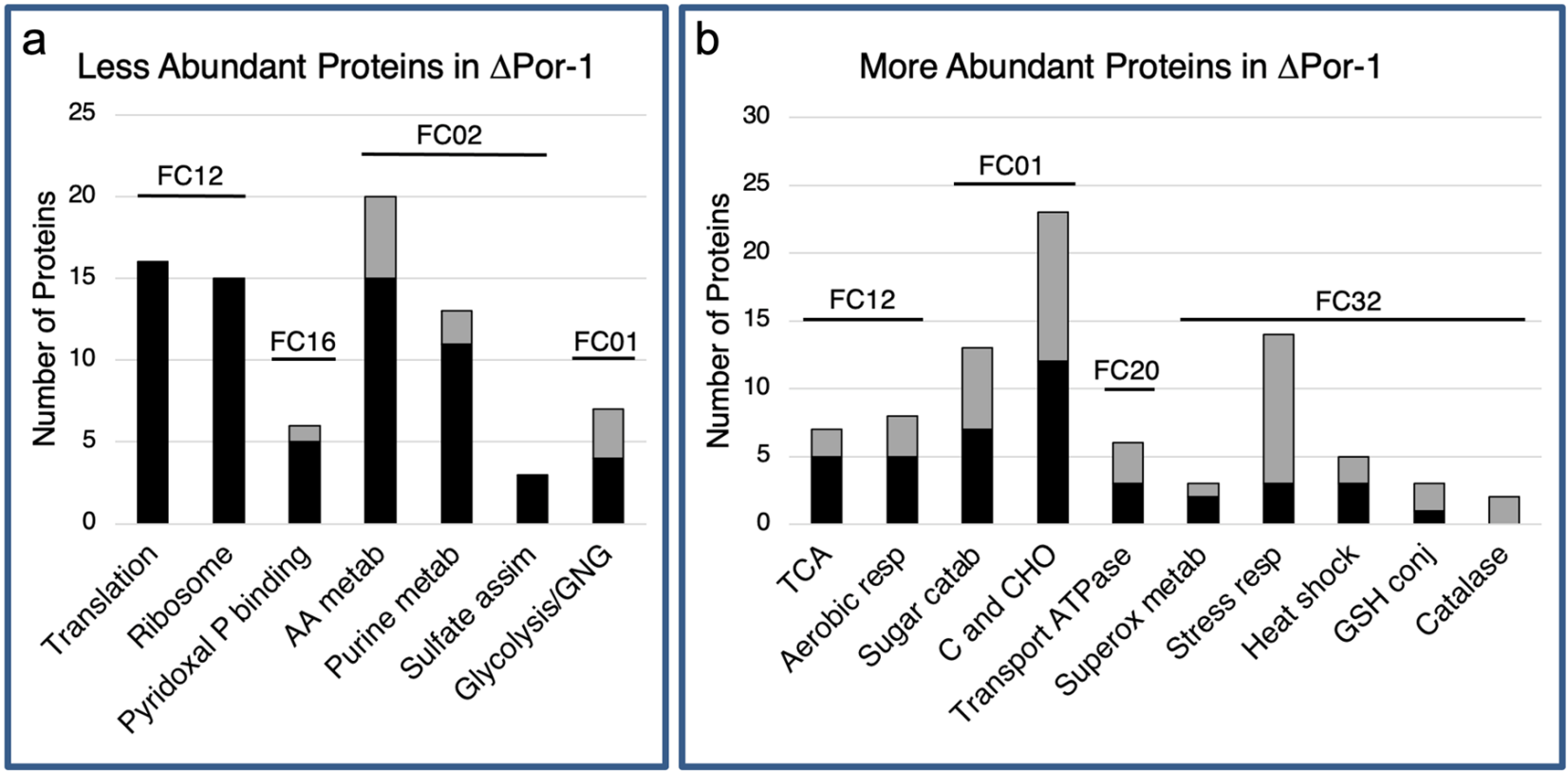

Figure 1. Classification of less and more abundant proteins in $\Delta$ Por- 1 . The proteins used in this functional category analysis were at lower (a) or higher (b) levels in the mutant than in WT cells (Tables S5 and S6). FungiFun2 (https:/ / elbe.hki-jena.de/fungifun/fungifun.php, accessed on 25 November 2017) was used to predict the categories of the proteins highly represented among these proteins, by using the FunCat classification database [42]. This analysis highlights biological processes for which there is a relative enrichment of related proteins [42]; therefore, not all proteins in different amounts are represented in the output. Numbered lines above the bars indicate the main FunCat (FC) categories identified: 12, protein synthesis; 16 , proteins with binding function; 02, energy; and 01, metabolism; cellular transport, transport facilitation and transport routes (20) and cell rescue, defence, and virulence (32). The black section of each bar indicates the number of S100 cytosol-enriched proteins, and the grey section indicates the mitochondrial proteins as defined in [14]. Abbreviations: (a) Pyridoxial P: pyridoxal phosphate binding proteins; AA metab: amino acid metabolism; Pu metab: purine nucleotide/nucleobase metabolism; sulfate assim: sulfate assimilation; glyco/GNG: glycolysis and gluconeogenesis. (b) TCA: tricarboxylic acid cycle; Aerobic resp: aerobic respiration; $\mathrm{C}$ and $\mathrm{CHO}$ : Carbon-compound and carbohydrate metabolism; Superox metab: superoxide metabolism; Stress resp: stress response; GHS conj: glutathione conjugation.

In terms of energy metabolism, the differential levels of some enzymes in $\Delta$ Por- 1 can be expected to impact metabolism of pyruvate (Figure $2 b, c)$. Increased levels of lactate dehydrogenase (Table S6) and decreased levels of pyruvate kinase and phosphoenolpyruvate carboxykinase (Table S5) could contribute to maintaining the pool of pyruvate. The enzymes in the TCA cycle were present at similar levels in the two strains, with the exception of succinyl CoA ligase (Figure 2c).

Several enzymes involved in different aspects of nucleic acid metabolism were differentially expressed, including adenylate kinase (Table S4), which is responsible for the interconversion of AMP, ADP, and ATP, which is a part of maintaining the energy balance in a cell (see [43]). Increased levels of adenylate kinase are compatible with the reduced state 3 respiration observed for $\Delta$ Por-1 mitochondria [13] (see below). 


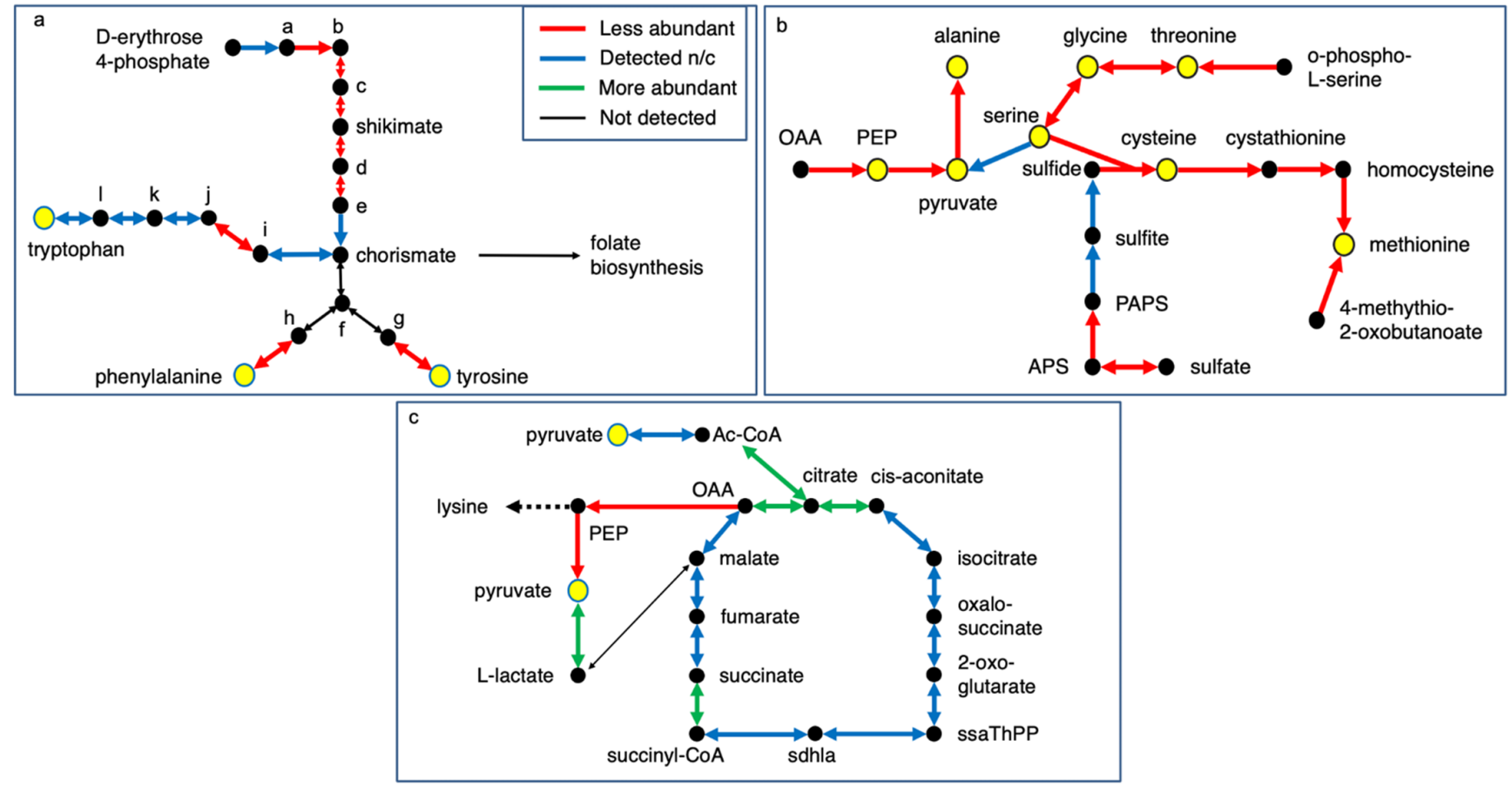

Figure 2. Metabolic pathway that includes proteins present at non-wild-type levels in $\Delta$ Por- 1 . Pathway details were obtained from KEGG pathways (https:/ / www.genome.jp/kegg/pathway.html, accessed 21 November 2021, [44]) and only the segments of pathways that include proteins in relatively higher or lower amounts are shown for clarity. (a) Shikimate pathway and aromatic amino acid biosynthesis (KEGG pathways shikimate ncr00400 and sulfur amino acids ncr00920, respectively). Intermediates are as follows: panel A: a: 7-phospho-2-dehydro-3-deoxy-D-arabinoheptonate; b: 3-dehydroxyquinate; c: 3-dehydroshikamate; d: shikimate 3-phosphate; e: 5-O-(1carboxyvinyl)-3-phosphoshikamate; f: prephenate; g: 4-hydroxy-phenylpyruvate; h: phenylpyruvate; i: anthranilate; j: N-(5-phospho- $\beta$-D-ribosyl)-anthranilate; k: 1-(2-carboxyphenylamino)-1'-deoxyD-ribulose-5-phosphate. (b) Amino acid biosynthesis (ncr00260, ncr00270) and sulfur metabolism (ncr00920) APS: adenosine $5^{\prime}$ phosphosulfate; PAPS: $3^{\prime}$ phosphoadenosine $5^{\prime}$ phosphosulfate: OAA: oxaloacetate; PEP, phosphoenolpyruvate (c) TCA cycle and pyruvate metabolism (ncr00020 and ncr00620) AcCoA: acetyl coenzyme A; ssaThPP: succinate semialdehyde thiamine diphosphate; sdhla: s-succinyldihydrolipoamide-E.

\subsection{More Abundant Proteins in $\Delta$ Por-1}

In the absence of VDAC, the more abundant proteins (Table S6) represent the following: FC 01, metabolism; FC 02, energy; FC 20, cellular transport, transport facilitation and transport routes, and FC 32, cell rescue, defence, and virulence (Figure 1b). In $\triangle$ Por- 1 , there were low levels of ETC complex I (NADH dehydrogenase) and low levels of the heme groups associated with complexes III $\left(\mathrm{CoQH}_{2}\right.$-cytochrome $\mathrm{c}$ reductase) and IV (cytochrome c oxidase). In contrast, there were increased levels of cytochrome $c$, higher alternative NADH dehydrogenase activity, and alternative oxidase was expressed [12-14]. Together, these factors and others allow isolated $\Delta$ Por- 1 mitochondria to maintain a normal membrane potential $(\Delta \psi)$ and oxygen consumption rate (OCR) in the presence of substrate (succinate) when ADP is not available, i.e., non-phosphorylating conditions (state 2 respiration) [3]. However, in the $\triangle$ Por- 1 mitochondria, the addition of ADP to induce consumption of the potential by ATP synthase (phosphorylating conditions, state 3 ) is associated with smaller increases in OCR and smaller decreases in $\Delta \psi$ than occur in WT mitochondria [13]. This indicates insufficiencies in the ETC. As expected, other proteins that are more abundant in $\Delta$ Por- 1 are linked to the electron flow and the ETC-protoheme IX farnesyltransferase, involved in heme a (cytochrome oxidase) synthesis [45], a Mam33 homologue involved in mitochondrial ribosome synthesis [46], the $\alpha$ subunit of the electron transfer flavoprotein, 
which interacts with multiple dehydrogenases [47], two subunits of the ATP synthase, and the cytochrome c apoprotein (Table S6).

Over-represented proteins in FC 20 (cellular transport, transport facilitation and transport routes; Table S6C) did not include an obvious candidate to replace VDAC as a general transport pore in the MOM. They did include components of the F-type mitochondrial ATPases and may relate to defects in oxidative phosphorylation [13]. Several subunits of vacuolar ATPases were also increased in $\triangle$ Por-1. These proteins generate an electrochemical gradient to transport molecules into vacuoles and create an acidic environment for the hydrolytic enzymes therein [48]. Degradation in vacuoles and recycling of the cellular materials [49] may be important for the survival of $\Delta$ Por- 1 cells. The remaining types of ATP transport proteins are members of the $\mathrm{ABC}$ and multidrug transporter families, but their substrates are not known.

More abundant proteins in the FunCat category FC 32: cell rescue, defence, and virulence; include catalases, involved in superoxide metabolism, and proteins in the glutathione conjugate reaction (Table S6D). Increased intracellular ROS has been observed in Saccharomyces cerevisiae lacking VDAC [50], and VDAC may be involved in the release of superoxide from mitochondria [51,52]. Enhanced cytosolic activity was detected in $\Delta$ Por- 1 compared to WT cells (Table 2), suggesting the cells are undergoing an oxidative stress response. This hypothesis is supported by a relative increase in reactive oxygen species in WT and $\Delta$ Por-1 strains, as detected with $2^{\prime}, 7^{\prime}$ dichlorofluorescein (Table 2). N. crassa expresses multiple superoxide dismutases (SOD): a Cu/Zn SOD (Sod-1; NCU02133) in the cytoplasm, a Mn-containing mitochondrial enzyme, Sod-2 (NCU01213), a dual-localized enzyme (Sod-3, NCU09560) in mitochondria and the cytosol, and an Fe-containing SOD (NCU07386). Sod-3 was present in increased amounts in the S100 fraction, while the levels of the other three SODs were similar in both strains (Tables S3 and S4).

Table 2. Characteristics of $\Delta$ Por-1 strains.

\begin{tabular}{ccc}
\hline Measurement & WT & $\Delta$ Por-1 \\
\hline${ }^{1}$ Catalase (cytoplasm, U/mg) & $45.8+/-3.3$ & $95.5+/-21.9$ \\
\hline${ }^{2}$ Intracellular ROS relative to WT (\%) & 100 & $150+/-50$ \\
\hline${ }^{3}$ Growth rate in the absence of tunicamycin & $11.7+/-0.1$ & $4.1+/-0.7$ \\
or with $2.5 \mu g / m L$ tunicamycin (cm/day) & $2.7+/-0.8$ & no growth \\
\hline${ }^{4}$ Ergosterol content (\% relative to WT) & $100+/-16.8$ & $59.6+/-9.4$ \\
\hline
\end{tabular}

${ }^{1}$ Catalase activity was measured as described in Materials and Methods, and values were normalized to the mass of cytoplasmic protein in the assay. One unit (U) of catalase decomposes $1 \mu$ mole of $\mathrm{H}_{2} \mathrm{O}_{2}$ in $1 \mathrm{~min}$ in a $60 \mathrm{mM}$ of $\mathrm{H}_{2} \mathrm{O}_{2}$ solution at $\mathrm{pH}$ 7.0. Average and standard deviations $(n=3$ or 4$)$ are presented. WT and $\Delta$ Por- 1 values were different $p<0.05$ based on a Student's $t$ test. ${ }^{2}$ The ratio of fluorescence of $2^{\prime}, 7^{\prime}$ dichlorofluorescein at $524 \mathrm{~nm}$ was used to compare intracellular ROS in WT and $\Delta$ Por- 1 strains. Fluorescence intensity was normalized to the mass of cellular protein in the sample, and the value for WT was set to $100 \%$. The results represent the ratios of normalized fluorescence in $\Delta$ Por-1 to WT for 4 pairs of biological replicates, with 2-3 technical replicates per sample. $p<0.1^{3}$ Linear growth was measured in "race tubes" containing solid Vogel's medium containing $2 \mu \mathrm{g} / \mathrm{mL}$ of tunicamycin. Following inoculation of one end of the tube with conidia, linear growth was measured and used to calculate rate in $\mathrm{cm} /$ day. WT data from [12]. ${ }^{4}$ Ergosterol content was measured as described in Materials and Methods, and the WT value was set to $100 \%$.

To further investigate the possible oxidative stress response, the group of more abundant proteins in $\Delta$ Por-1 was compared to those predicted to be upregulated based on the transcriptome analysis of $N$. crassa treated with menadione, an inducer of oxidative stress [53]. About $15 \%$ of the more abundant proteins in $\Delta$ Por- 1 were predicted to be overexpressed in menadione-treated cells; this group includes catalases 2 and 3 and a glutathione S-transferase (Table 3). In terms of more abundant proteins, 12 of those in $\Delta$ Por-1 were also more abundant in menadione-treated, oxidatively stressed cells (Figure 3). However, only some of the predicted metabolic changes in the $\Delta$ Por- 1 cells may reflect an oxidative stress response. 
Table 3. More abundant proteins shared among $\Delta$ Por-1, oxidatively stressed cells and cells undergoing unfolded protein response in the ER.

\begin{tabular}{|c|c|c|c|}
\hline \multicolumn{2}{|c|}{$\begin{array}{l}\text { A. More Abundant Proteins in } \Delta \text { Por-1 and } \\
\text { Cells Undergoing UPR }\end{array}$} & \multicolumn{2}{|c|}{$\begin{array}{l}\text { B. More Abundant Proteins in } \Delta \text { Por-1 and } \\
\text { Menadione-Treated Cells }{ }^{2}\end{array}$} \\
\hline NCU05780 & glutathione S-transferase-1 & NCU05780 & glutathione S-transferase-1 \\
\hline NCU09519 & $\begin{array}{l}\text { 2,5-diketo-D-gluconic acid } \\
\text { reductase A }\end{array}$ & NCU09559 & clock-controlled gene-9 \\
\hline NCU10572 & short-chain oxidoreductase & NCU05770 & catalase-2 \\
\hline NCU01272 & $\begin{array}{c}\text { mitochondrial presequence } \\
\text { protease }\end{array}$ & NCU04930 & hypothetical protein \\
\hline NCU02549 & processing enhancing protein & NCU00355 & catalase- 3 \\
\hline NCU09559 & clock-controlled gene-9 & NCU09674 & O-methyltransferase family 3 \\
\hline NCU09560 & superoxide dismutase & NCU02812 & uridylate kinase \\
\hline NCU05770 & catalase-2 & NCU08402 & $\begin{array}{l}\text { zinc-binding alcohol } \\
\text { dehydrogenase }\end{array}$ \\
\hline NCU03739 & ERP38 protein & NCU02727 & $\begin{array}{c}\text { glycine cleavage system } \\
\text { T protein }\end{array}$ \\
\hline NCU04930 & hypothetical protein & NCU08004 & $\begin{array}{l}\text { electron transfer flavoprotein } \\
\text { alpha-subunit }\end{array}$ \\
\hline NCU01589 & heat-shock protein 60 & NCU06974 & histidinol-phosphatase \\
\hline NCU09674 & O-methyltransferase family 3 & NCU00685 & casein kinase I isoform delta \\
\hline NCU03611 & chitin synthase- 1 & & \\
\hline NCU03795 & cell division control protein 12 & & \\
\hline NCU03949 & nitropropane dioxygenase- 1 & \multicolumn{2}{|c|}{$\begin{array}{c}\text { C. More abundant proteins in } \Delta \text { Por-1, } \\
\text { menadione-treated cells and cells } \\
\text { undergoing UPR }\end{array}$} \\
\hline NCU05881 & $\begin{array}{l}\text { DUF500 and UBA/TS-N } \\
\text { domain-containing protein }\end{array}$ & NCU05780 & glutathione S-transferase-1 \\
\hline NCU10810 & mRNA-splicing protein & NCU09559 & clock-controlled gene-9 \\
\hline NCU02727 & $\begin{array}{c}\text { glycine cleavage system } \\
\text { T protein } \\
\end{array}$ & NCU05770 & catalase-2 \\
\hline NCU06738 & protein transporter sec-31 & NCU04930 & hypothetical protein \\
\hline NCU01166 & microcycle blastoconidiation & NCU09674 & O-methyltransferase family 3 \\
\hline NCU03596 & $\begin{array}{c}\text { CRAL/TRIO } \\
\text { domain-containing protein } \\
\end{array}$ & NCU02727 & $\begin{array}{c}\text { glycine cleavage system } \\
\text { T protein } \\
\end{array}$ \\
\hline NCU06974 & histidinol-phosphatase & NCU06974 & histidinol-phosphatase \\
\hline NCU00864 & $\begin{array}{l}\text { TIM-barrel enzyme } \\
\text { family protein }\end{array}$ & NCU00685 & casein kinase I isoform delta \\
\hline NCU09223 & protein disulfide-isomerase & & \\
\hline NCU10360 & hypothetical protein & & \\
\hline NCU05495 & clock-controlled gene-16 & & \\
\hline NCU01004 & $\begin{array}{c}\text { phosphatidylserine } \\
\text { decarboxylase proenzyme }\end{array}$ & & \\
\hline NCU00685 & casein kinase I isoform delta & & \\
\hline NCU00350 & epoxide hydrolase & & \\
\hline
\end{tabular}

${ }^{1} \mathrm{UPR}^{\mathrm{ER}}$ data from [29]; ${ }^{2}$ data from menadione-treated cells from [53].

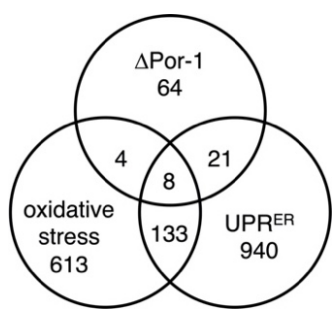

Figure 3. Proteins overexpressed under multiple conditions. The numbers in the overlapping circles indicate the number of proteins or RNA overexpressed in each group of conditions. Eight proteins were more abundant in all three conditions (glutathione S-transferase-1, clock-controlled gene-9, catalase-2, O-methyltransferase family 3, glycine, casein kinase I isoform delta, and hypothetical protein NCU04930). Proteins shared by two or more groups are listed in Table 3. Oxidative stress data were attained from [53] and UPRER data from [29]. 


\subsection{Unfolded Protein Responses}

In $\Delta$ Por-1, several proteins involved in the mitochondrial misfolded protein response $\left(\mathrm{UPR}^{\mathrm{mt}}\right)$ are more abundant than in WT cells [14]. The current study supports these results, as it revealed a relative increase in mitochondrial heat-shock protein 60 (hsp60; Table S6D), which is part of the UPR ${ }^{\mathrm{mt}}$ (reviewed in [54]). Levels of Hsp70-5 also increased, but the precise function and cellular location of this isoform have not been confirmed in N. crassa.

Protein disulfide isomerase (Pdi-1), a marker for the unfolded protein response of the endoplasmic reticulum (UPR ${ }^{\mathrm{ER}}$, [29]), was upregulated in $\triangle \mathrm{Por}-1$ (Table S4). In N. crassa, $\mathrm{UPR}^{\mathrm{ER}}$ is triggered when the unfolded protein sensor in the ER membrane, Ire1 (NCU02202), detects unfolded proteins in the lumen. This activates the RNAse domain of the protein, initiating splicing of HAC1 (NCU01856) mRNA to generate the open reading frame for the Hac1 transcription factor (see [28]). Ire1 and Hac1 were not detected in the S100, cytosol-enriched samples. The RNA ligase, TRL1/RLG1 (NCU04410), which completes the splicing process, was found in similar amounts in the S100 fraction of $\Delta$ Por- 1 and WT cells (Table S4). In further support of a UPR ${ }^{E R}$ response in $\triangle$ Por-1, it was noted that 29 of the 97 proteins present in high relative amounts in $\triangle$ Por-1 were also predicted from RNA levels to be upregulated in N. crassa under one or more $\mathrm{UPR}^{\mathrm{ER}}$-inducing conditions (presence of dithiothreitol (DTT) or Tunicamycin (TM); [29] (Table 3; Figure 3). Furthermore, two proteins involved in endoplasmic reticulum-associated degradation (ERAD) pathways (Hsp-40 and Pcb-1) were detected only in the $\Delta$ Por-1 strain (Table S4), suggesting that they are overexpressed. Therefore, we predicted that $\Delta$ Por- 1 would be more sensitive than WT to additional drug-induced misfolding of proteins in the ER, due to the presence of misfolded proteins associated with the lack of VDAC. Cells were treated with tunicamycin, which blocks the glycosylation of proteins in the ER, thereby inducing their misfolding [28]. The concentration used was sufficient to induce mild levels of stress in WT cells [28]. Slow growth was observed for WT in the presence of tunicamycin (Table 2), indicating that the cells could survive with the level of misfolded proteins induced by the drug. In contrast, no growth was observed in the $\Delta$ Por- 1 strain in the presence of tunicamycin, supporting the hypothesis that misfolded proteins are associated with the absence of VDAC and that further increases in their levels are fatal.

Taken together, the overall analysis is suggestive of active UPR ${ }^{\mathrm{ER}}$ in $\Delta$ Por-1 N. crassa, although conclusions drawn from comparisons of these preliminary proteomic analyses and transcriptomic studies need to be considered with caution.

\subsection{Hyphal Morphology}

Several proteins showing differential expression are linked to hyphal morphology. Two regulatory proteins involved in conidiation, Rco-1 (NCU06205), and Nrc-2 (NCU01797) were detected only in $\Delta$ Por-1, suggesting that they are upregulated in this mutant (Table S4). Intriguingly, the null mutants of rco-1 (regulator of conidiation-1) [55,56] and $\Delta$ Por- 1 showed reduced aerial hyphae and conidiation compared to WT (Figure 4), and female sterility [12]. Non-repressible conidiation gene \#2 (nrc-2) encodes a serine/threonine kinase required to repress the initiation of conidiation under nutrient-sufficient conditions [57] and therefore, its overexpression is expected to repress conidiation. $\Delta$ Por- 1 exhibited a very low level of conidiation (Figure 4a), suggesting that the phenotype was impacted most by the increased levels of Nrc-2. $\Delta$ Por-1 hyphae (Figure $4 \mathrm{~b}$ ) showed a higher degree of branching than WT hyphae (Figure 4c), but the reason for this phenotype is unknown. 

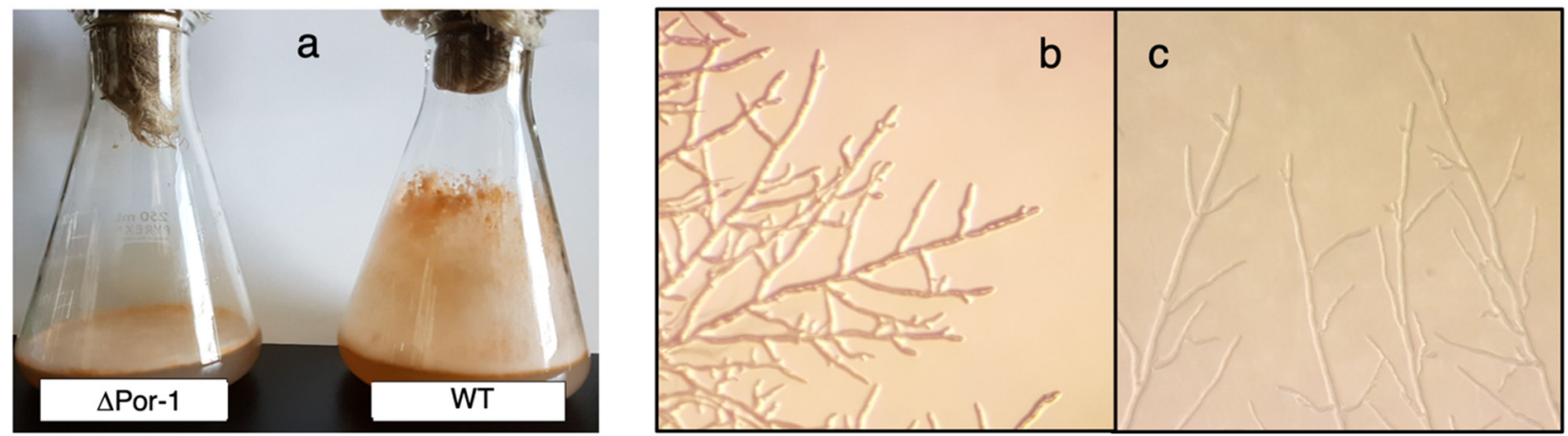

Figure 4. Morphology of $\Delta$ Por- $1 . \Delta$ Por-1 and WT N. crassa were grown on solidified VM medium; flasks were incubated in the dark for 3 days and 7 days for WT and $\Delta$ Por- 1 , respectively, and subsequently transferred to the light for 3 days to promote conidiation. In the WT, aerial hyphae were observed as growth on the surface of the flask above the medium, and orange clusters of conidia are seen at the growth front. (a) In $\Delta$ Por-1, aerial hyphae were not observed, and there was a small amount of conidia at the surface of the medium. Hyphal morphology of $\Delta$ Por- 1 (b) and WT (c). Cells were grown on a VM plate for $12 \mathrm{~h}$ and $24 \mathrm{~h}$ at $30^{\circ} \mathrm{C}$ for WT and $\Delta$ Por-1, respectively. Plates were observed directly with a Leica Wild M8 stereomicroscope (Wild Heerbrugg, Ottawa, ON, Canada) and the resulting images are presented at $60 \times$ magnification.

\subsection{Mitochondrial Membranes}

The $\Delta$ Por-1 N. crassa strain was cold-sensitive and displayed abnormal mitochondrial morphology [12]. These phenotypes likely reflect membrane characteristics in addition to changes in membrane proteomes. As a first step to investigate membranes of $\Delta$ Por- 1 mitochondria, fluorescence of the probe Laurdan was utilized to assess overall membrane fluidity (Figure 5a). One relative measure of membrane fluidity is the ratio of Laurdan fluorescence at $440 \mathrm{~nm}$ to that at $490 \mathrm{~nm}$ (F440/F490); a higher ratio is indicative of lower fluidity because the emission of the probe shifts towards the red end of the spectrum (approximately $490 \mathrm{~nm}$ ) when the membrane is in the fluid phase $[36,58,59]$.

a

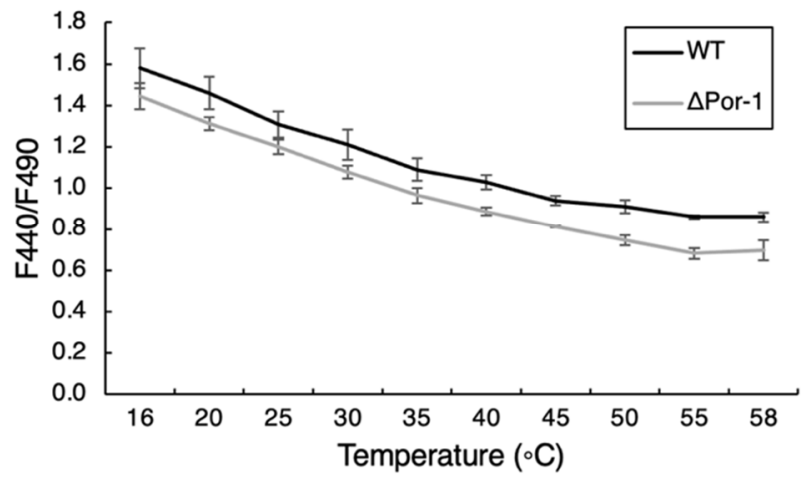

b

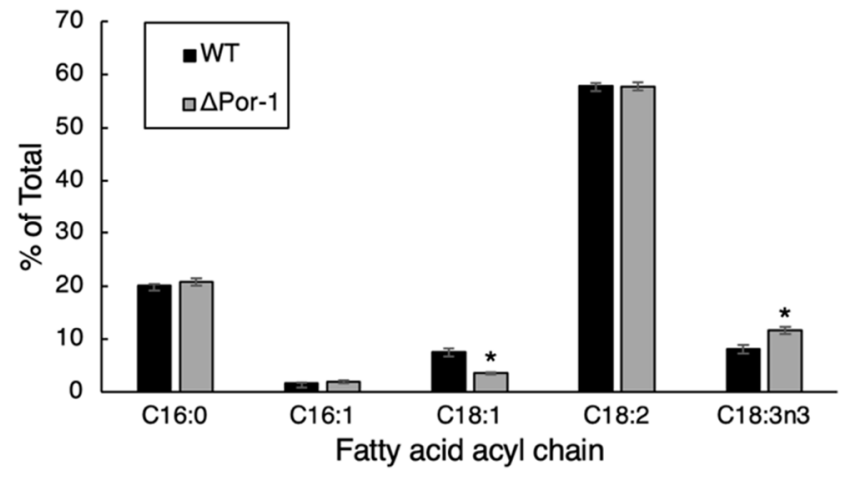

Figure 5. Non-protein components of $\Delta$ Por-1 mitochondrial membranes. (a) Fluidity of mitochondrial membranes. F440/F490 ratios of Laurdan interacting with WT and $\Delta$ Por-1 mitochondria at increasing temperatures. Error bars indicate standard deviation of the samples $(n=4)$. (b) Acyl chain analysis of WT and $\Delta$ Por- 1 mitochondrial phospholipids. The most abundant acyl chains are shown in the graph, and each is represented as the percentage of the total for that strain. * indicates significance at a $p<0.05$ based on a Student's $t$-test. $(n=3-4)$. Error bars indicate standard deviation of the samples.

Analysis of whole mitochondrial membranes (Figure $5 \mathrm{a}$ ) suggests that at $30{ }^{\circ} \mathrm{C}$, the membranes in $\Delta$ Por- 1 were slightly more fluid than those of the WT, and this trend continued as the membrane sample was heated. Acyl chains of mitochondrial phospholipids 
and sterol composition were measured, as both can influence the fluidity of the membrane $[60,61]$. The predominant acyl chain species were very similar in the two strains (Figure $5 \mathrm{~b}$ ), but in the WT strain, the ratio of C18:1 to C18:3n3 acyl chains was higher relative to that in $\Delta$ Por- 1 . The increased fraction of polyunsaturated fatty acids might contribute to increased membrane fluidity in $\Delta$ Por-1. Sterol levels also influence membrane fluidity [62]. In $\Delta$ Por-1, the amount of ergosterol was lower compared to WT (Table 2), which is expected to increase fluidity $[60,63]$. Together, these observations suggest a combination of factors affecting physical differences in the lipid environment between $\Delta \mathrm{Por}-1$ and WT mitochondria. Membrane fluidity can be influenced by other factors, such as the nature of the polar head groups on the lipids [64]. Detailed analysis of purified inner and outer membranes is required to gain a more complete understanding of the altered membrane properties detected in this study.

\section{Conclusions}

In this study, preliminary proteomic analysis of mitochondrial and S100, cytosolenriched protein samples provided insights into the mechanisms related to survival of $N$. crassa in the absence of its single isoform of VDAC. In general, proteins involved in oxidative stress responses were more abundant, suggesting increased levels of reactive oxygen species (ROS), as predicted from recent work demonstrating that $\Delta$ Por-1 mitochondria have an increased capacity for ROS production [13] and comparisons of whole-cell ROS levels (Table 2). Global comparisons of the preliminary $\Delta$ Por-1 proteome with predictions based on transcriptomes studies revealed proteins that were more abundant in $\Delta$ Por- 1 cells and in WT cells undergoing oxidative stress [53]. Similarly, about $25 \%$ of the more abundant proteins detected in $\triangle$ Por- 1 are also more abundant in cells with activated $\mathrm{UPR}^{\mathrm{ER}}$, suggesting that part of the response to the absence of VDAC is related to defects in protein folding.

Proteins and enzymes in pathways related to amino acid and protein synthesis were found in relatively low amounts, which is compatible with the slow growth of $\Delta$ Por- 1 . In addition, the acyl chain composition of phospholipids and the abundance of ergosterol were different in $\triangle$ Por-1 and WT cells, and this may play a role in altering the physical properties of mitochondrial membranes. Thus, these initial findings indicate that the absence of VDAC induces stress responses and impacts many aspects of cellular structure and function. The mechanism(s) by which substrates and products cross the MOM in $\triangle$ Por- 1 cells, thereby allowing their survival, remains an intriguing problem for future study.

Supplementary Materials: The following are available online at https:/ / www.mdpi.com/article/10 .3390/microorganisms10020198/s1, Table S1: MS/MS spectra data and scatter plots of replicates of S100 cytosolic data. Table S2: composition of S100 and mitochondria-enriched fractions. Table S3: mitochondrial proteome data. Table S4: S100 cytosolic proteome data. Table S5: categories of proteins enriched the pool of downregulated proteins in $\triangle$ Por-1. Table S6: categories of proteins enriched the pool of upregulated proteins in $\Delta$ Por- 1 .

Author Contributions: Conceptualization, S.R.S., A.M. and D.A.C.; methodology and formal analysis S.R.S., A.M., O.V.K., V.S. and D.A.C., writing, review and editing, S.R.S., A.M. and D.A.C. All authors have read and agreed to the published version of the manuscript.

Funding: This research was funded by a Discovery Grant from the Natural Sciences and Engineering Research Council of Canada (NSERC, RGPIN-2016-05930) to D.A.C., S.R.S. acknowledges support from the Faculty of Graduate Studies at the University of Manitoba (UMGF and GETS); A.M. was supported by an NSERC PGS-M award and a Faculty of Science award from the University of Manitoba.

Data Availability Statement: Data are available in supplementary files.

Acknowledgments: We would like to thank Fraser Ferens, Department of Microbiology, for his valuable comments and Michael Adeyemi for assistance with the pathway analysis. We would also like to thank Jacek Switala, Department of Microbiology, for his help with the catalase activity measurements, Dennis Labossiere, Department of Food and Human Nutritional Sciences, for his help with lipid and 
sterol analysis and Peyman Ezzati, Manitoba Centre for Proteomics and Systems Biology, for assisting with proteomic analysis. We also express our gratitude to Georg Hausner, Department of Microbiology, Ayush Kumar, Department of Microbiology, and Jason Treberg, Department of Biological Sciences, for assistance with the stereomicroscope, plate reader, and fluorimeter, respectively.

Conflicts of Interest: The authors declare no conflict of interest.

\section{References}

1. Bay, D.C.; Hafez, M.; Young, M.J.; Court, D.A. Phylogenetic and coevolutionary analysis of the $\beta$-barrel protein family comprised of mitochondrial porin (VDAC) and Tom. Biochim. Biophys. Acta (BBA) Biomembr. 2012, 1818, 1502-1519. [CrossRef]

2. $\quad$ Bayrhuber, M.; Meins, T.; Habeck, M.; Becker, S.; Giller, K.; Villinger, S.; Vonrhein, C.; Griesinger, C.; Zweckstetter, M.; Zeth, K. Structure of the human voltage-dependent anion channel. Proc. Natl. Acad. Sci. USA 2008, 105, 15370-15375. [CrossRef]

3. Hiller, S.; Garces, R.G.; Malia, T.J.; Orekhov, V.Y.; Colombini, M.; Wagner, G. Solution Structure of the Integral Human Membrane Protein VDAC-1 in Detergent Micelles. Science 2008, 321, 1206-1210. [CrossRef]

4. Ujwal, R.; Cascio, D.; Colletier, J.-P.; Faham, S.; Zhang, J.; Toro, L.; Ping, P.; Abramson, J. The crystal structure of mouse VDAC1 at $2.3 \AA$ resolution reveals mechanistic insights into metabolite gating. Proc. Natl. Acad. Sci. USA 2008, 105, 17742-17747. [CrossRef]

5. Rostovtseva, T.; Colombini, M. VDAC channels mediate and gate the flow of ATP: Implications for the regulation of mitochondrial function. Biophys. J. 1997, 72, 1954-1962. [CrossRef]

6. Benz, R.; Schmid, A.; Dihanich, M. Pores from mitochondrial outer membranes of yeast and a porin-deficient yeast mutant: A comparison. J. Bioenerg. Biomembr. 1989, 21, 439-450. [CrossRef]

7. Mannella, C.A. Electron microscopy and image analysis of the mitochondrial outer membrane channel, VDAC. J. Bioenerg. Biomembr. 1987, 19, 329-340. [CrossRef]

8. Shuvo, S.R.; Ferens, F.G.; Court, D.A. The N-terminus of VDAC: Structure, mutational analysis, and a potential role in regulating barrel shape. Biochim. Biophys. Acta (BBA) Biomembr. 2016, 1858, 1350-1361. [CrossRef]

9. Najbauer, E.E.; Becker, S.; Giller, K.; Zweckstetter, M.; Lange, A.; Steinem, C.; de Groot, B.L.; Griesinger, C.; Andreas, L.B. Structure, gating and interactions of the voltage-dependent anion channel. Eur. Biophys. J. 2021, 50, 159-172. [CrossRef]

10. Preto, J.; Krimm, I. The intrinsically disordered N-terminus of the voltage-dependent anion channel. PLoS Comput. Biol. 2021, 17, e1008750. [CrossRef]

11. Nargang, F.E.; Rapaport, D. Neurospora crassa as a Model Organism for Mitochondrial Biogenesis. Methods Mol. Biol. 2007, 372, 107-123. [CrossRef] [PubMed]

12. Summers, W.A.; Wilkins, J.A.; Dwivedi, R.C.; Ezzati, P.; Court, D.A. Mitochondrial dysfunction resulting from the absence of mitochondrial porin in Neurospora crassa. Mitochondrion 2012, 12, 220-229. [CrossRef] [PubMed]

13. Shuvo, S.R.; Wiens, L.M.; Subramaniam, S.; Treberg, J.R.; Court, D.A. Increased reactive oxygen species production and maintenance of membrane potential in VDAC-less Neurospora crassa mitochondria. J. Bioenerg. Biomembr. 2019, 51, 341-354. [CrossRef] [PubMed]

14. Ferens, F.G.; Spicer, V.; Krokhin, O.V.; Motnenko, A.; Summers, W.A.; Court, D.A. A deletion variant partially complements a porin-less strain of Neurospora crassa. Biochem. Cell Biol. 2017, 95, 318-327. [CrossRef]

15. Colot, H.V.; Park, G.; Turner, G.E.; Ringelberg, C.; Crew, C.M.; Litvinkova, L.; Weiss, R.L.; Borkovich, K.A.; Dunlap, J.C. A high-throughput gene knockout procedure for Neurospora reveals functions for multiple transcription factors. Proc. Natl. Acad. Sci. USA 2006, 103, 10352-10357. [CrossRef]

16. McCluskey, K.; Wiest, A.; Plamann, M. The Fungal Genetics Stock Center: A repository for 50 years of fungal genetics research. J. Biosci. 2010, 35, 119-126. [CrossRef] [PubMed]

17. Davis, R.H.; de Serres, F.J. Genetic and microbiological research techniques for Neurospora crassa. Methods Methane Metab. Part B Methanotrophy 1970, 17, 79-143. [CrossRef]

18. Harkness, T.; Nargang, F.E.; Van der Klei, I.J.; Neupert, W.; Lill, R. A crucial role of the mitochondrial protein import receptor MOM19 for the biogenesis of mitochondria. J. Cell Biol. 1994, 124, 637-648. [CrossRef]

19. Ferens, F.G.; Summers, W.A.T.; Bharaj, A.; Stetefeld, J.; Court, D.A. A C-Terminally Truncated Variant of Neurospora crassa VDAC Assembles into a Partially Functional Form in the Mitochondrial Outer Membrane and Forms Multimers in vitro. Front. Physiol. 2021, 12, 739001. [CrossRef]

20. Wiśniewski, J.R.; Zougman, A.; Nagaraj, N.; Mann, M. Universal sample preparation method for proteome analysis. Nat. Methods 2009, 6, 359-362. [CrossRef]

21. Dwivedi, R.C.; Spicer, V.; Harder, M.; Antonovici, M.; Ens, W.; Standing, K.G.; Wilkins, J.A.; Krokhin, O.V. Practical Implementation of 2D HPLC Scheme with Accurate Peptide Retention Prediction in Both Dimensions for High-Throughput Bottom-Up Proteomics. Anal. Chem. 2008, 80, 7036-7042. [CrossRef]

22. Michelsen, U.; von Hagen, J. Chapter 19 Isolation of Subcellular Organelles and Structures. Methods Enzymol. 2009, 463, 305-328. [CrossRef] [PubMed]

23. Craig, R.; Beavis, R.C. TANDEM: Matching proteins with tandem mass spectra. Bioinformatics 2004, 20, 1466-1467. [CrossRef] 
24. McQueen, P.; Spicer, V.; Rydzak, T.; Sparling, R.; Levin, D.; Wilkins, J.A.; Krokhin, O. Information-dependent LC-MS/MS acquisition with exclusion lists potentially generated on-the-fly: Case study using a whole cell digest of Clostridium thermocellum. Proteomics 2012, 12, 1160-1169. [CrossRef] [PubMed]

25. Gungormusler-Yilmaz, M.; Shamshurin, D.; Grigoryan, M.; Taillefer, M.; Spicer, V.; Krokhin, O.V.; Sparling, R.; Levin, D.B. Reduced catabolic protein expression in Clostridium butyricum DSM 10702 correlate with reduced 1,3-propanediol synthesis at high glycerol loading. AMB Express 2014, 4, 63. [CrossRef] [PubMed]

26. McQueen, P.; Spicer, V.; Schellenberg, J.; Krokhin, O.; Sparling, R.; Levin, D.; Wilkins, J.A. Whole cell, label free protein quantitation with data independent acquisition: Quantitation at the MS2 level. Proteomics 2015, 15, 16-24. [CrossRef]

27. Wushke, S.; Spicer, V.; Zhang, X.L.; Fristensky, B.; Krokhin, O.V.; Levin, D.B.; Cicek, N.; Sparling, R. Understanding aerobic/anaerobic metabolism in Caldibacillus debilis through a comparison with model organisms. Syst. Appl. Microbiol. 2017, 40, 245-253. [CrossRef]

28. Montenegro-Montero, A.; Goity, A.; Larrondo, L.F. The bZIP Transcription Factor HAC-1 Is Involved in the Unfolded Protein Response and Is Necessary for Growth on Cellulose in Neurospora crassa. PLoS ONE 2015, 10, e0131415. [CrossRef]

29. Fan, F.; Ma, G.; Li, J.; Liu, Q.; Benz, J.P.; Tian, C.; Ma, Y. Genome-wide analysis of the endoplasmic reticulum stress response during lignocellulase production in Neurospora crassa. Biotechnol. Biofuels 2015, 8, 1-17. [CrossRef]

30. Karaffa, L.; Váczy, K.Z.; Sándor, E.; Biró, S.; Szentirmai, A.; Pócsi, I. Cyanide-resistant alternative respiration is strictly correlated to intracellular peroxide levels in Acremonium chrysogenum. Free. Radic. Res. 2001, 34, 405-416. [CrossRef]

31. Fernandes, P.N.; Mannarino, S.C.; Silva, C.G.; Pereira, M.D.; Panek, A.D.; Eleutherio, E.C. Oxidative stress response in eukaryotes: Effect of glutathione, superoxide dismutase and catalase on adaptation to peroxide and menadione stresses in Saccharomyces cerevisiae. Redox Rep. 2007, 12, 236-244. [CrossRef]

32. Loewen, P.C.; Villanueva, J.; Switala, J.; Donald, L.J.; Ivancich, A. Unprecedented access of phenolic substrates to the heme active site of a catalase: Substrate binding and peroxidase-like reactivity of Bacillus pumilus catalase monitored by X-ray crystallography and EPR spectroscopy. Proteins Struct. Funct. Bioinform. 2015, 83, 853-866. [CrossRef] [PubMed]

33. Sestric, R.; Munch, G.; Cicek, N.; Sparling, R.; Levin, D.B. Growth and neutral lipid synthesis by Yarrowia lipolytica on various carbon substrates under nutrient-sufficient and nutrient-limited conditions. Bioresour. Technol. 2014, 164, 41-46. [CrossRef] [PubMed]

34. Larsson, L.; Saraf, A. Use of gas chromatography-ion trap tandem mass spectrometry for the detection and characterization of microorganisms in complex samples. Mol. Biotechnol. 1997, 7, 279-287. [CrossRef]

35. Moghadasian, M.H.; Moghadasian, P.; Le, K.; Hydamaka, A.; Zahradka, P. Lipid analyses of four types of fish from Manitoba lakes. E Cronicon Nutr. 2015, 1, 41-48.

36. Bari, M.; Battista, N.; Fezza, F.; Finazzi-Agrò, A.; Maccarrone, M. Lipid Rafts Control Signaling of Type-1 Cannabinoid Receptors in Neuronal Cells. J. Biol. Chem. 2005, 280, 12212-12220. [CrossRef] [PubMed]

37. Ruepp, A.; Zollner, A.; Maier, D.; Albermann, K.; Hani, J.; Mokrejs, M.; Tetko, I.; Güldener, U.; Mannhaupt, G.; Münsterkötter, M.; et al. The FunCat, a functional annotation scheme for systematic classification of proteins from whole genomes. Nucleic Acids Res. 2004, 32, 5539-5545. [CrossRef]

38. Castilho, B.A.; Shanmugam, R.; Silva, R.; Ramesh, R.; Himme, B.M.; Sattlegger, E. Keeping the eIF2 alpha kinase Gcn2 in check. Biochim. Biophys. Acta 2014, 1843, 1948-1968. [CrossRef]

39. Carsiotis, M.; Jones, R.F. Cross-Pathway Regulation: Tryptophan-Mediated Control of Histidine and Arginine Biosynthetic Enzymes in Neurospora crassa. J. Bacteriol. 1974, 119, 889-892. [CrossRef]

40. Barthelmess, I.B. Regulation of amino acid synthetic enzymes in Neurospora crassa in the presence of high concentrations of amino acids. Mol. Genet. Genom. 1986, 203, 533-537. [CrossRef]

41. Paluh, J.; Orbach, M.J.; Legerton, T.L.; Yanofsky, C. The cross-pathway control gene of Neurospora crassa, cpc-1, encodes a protein similar to GCN4 of yeast and the DNA-binding domain of the oncogene v-jun-encoded protein. Proc. Natl. Acad. Sci. USA 1988, 85, 3728-3732. [CrossRef]

42. Priebe, S.; Kreisel, C.; Horn, F.; Guthke, R.; Linde, J. FungiFun2: A comprehensive online resource for systematic analysis of gene lists from fungal species. Bioinformatics 2015, 31, 445-446. [CrossRef] [PubMed]

43. Tükenmez, H.; Magnussen, H.M.; Kovermann, M.; Byström, A.; Wolf-Watz, M. Linkage between Fitness of Yeast Cells and Adenylate Kinase Catalysis. PLoS ONE 2016, 11, e0163115. [CrossRef] [PubMed]

44. Kanehisa, M.; Sato, Y.; Kawashima, M.; Furumichi, M.; Tanabe, M. KEGG as a reference resource for gene and protein annotation. Nucleic Acids Res. 2016, 44, D457-D462. [CrossRef] [PubMed]

45. Moraes, C.T.; Diaz, F.; Barrientos, A. Defects in the biosynthesis of mitochondrial heme $\mathrm{c}$ and heme a in yeast and mammals. Biochim. Biophys. Acta (BBA) Bioenerg. 2004, 1659, 153-159. [CrossRef]

46. Hillman, G.A.; Henry, M.F. The yeast protein Mam33 functions in the assembly of the mitochondrial ribosome. J. Biol. Chem. 2019, 294, 9813-9829. [CrossRef] [PubMed]

47. Salazar, D.; Zhang, L.; Degala, G.D.; Frerman, F.E. Expression and Characterization of Two Pathogenic Mutations in Human Electron Transfer Flavoprotein. J. Biol. Chem. 1997, 272, 26425-26433. [CrossRef] [PubMed]

48. Margolles-Clark, E.; Tenney, K.; Bowman, E.J.; Bowman, B.J. The structure of the vacuolar ATPase in Neurospora crassa. J. Bioenerg. Biomembr. 1999, 31, 29-37. [CrossRef] 
49. Plesofsky, N.; Higgins, L.; Markowski, T.; Brambl, R. Glucose Starvation Alters Heat Shock Response, Leading to Death of Wild Type Cells and Survival of MAP Kinase Signaling Mutant. PLoS ONE 2016, 11, e0165980. [CrossRef]

50. Reina, S.; Palermo, V.; Guarnera, A.; Guarino, F.; Messina, A.; Mazzoni, C.; De Pinto, V. Swapping of the N-terminus of VDAC1 with VDAC3 restores full activity of the channel and confers anti-aging features to the cell. FEBS Lett. 2010, 584, $2837-2844$. [CrossRef]

51. Madesh, M.; Hajnóczky, G. VDAC-dependent permeabilization of the outer mitochondrial membrane by superoxide induces rapid and massive cytochrome c release. J. Cell Biol. 2001, 155, 1003-1016. [CrossRef]

52. Shoshan-Barmatz, V.; Mizrachi, D. VDAC1: From structure to cancer therapy. Front. Oncol. 2012, 2, 164. [CrossRef]

53. Zhu, J.; Yu, X.; Xie, B.; Gu, X.; Zhang, Z.; Li, S. Transcriptomic profiling-based mutant screen reveals three new transcription factors mediating menadione resistance in Neurospora crassa. Fungal Biol. 2013, 117, 422-430. [CrossRef] [PubMed]

54. Pellegrino, M.W.; Nargund, A.M.; Haynes, C.M. Signaling the mitochondrial unfolded protein response. Biochim. Biophys. Acta (BBA) Bioenerg. 2012, 1833, 410-416. [CrossRef] [PubMed]

55. Watters, M.K.; Boersma, M.; Johnson, M.; Reyes, C.; Westrick, E.; Lindamood, E. A screen for Neurospora knockout mutants displaying growth rate dependent branch density. Fungal Biol. 2011, 115, 296-301. [CrossRef] [PubMed]

56. Yamashiro, C.T.; Ebbole, D.J.; Lee, B.U.; Brown, R.E.; Bourland, C.; Madi, L.; Yanofsky, C. Characterization of rco-1 of Neurospora crassa, a pleiotropic gene affecting growth and development that encodes a homolog of Tup1 of Saccharomyces cerevisiae. Mol. Cell. Biol. 1996, 16, 6218-6228. [CrossRef] [PubMed]

57. Kothe, G.O.; Free, S.J. The Isolation and Characterization of nrc-1 and nrc-2, Two Genes Encoding Protein Kinases That Control Growth and Development in Neurospora crassa. Genetics 1998, 149, 117-130. [CrossRef] [PubMed]

58. Catanzaro, G.; Rapino, C.; Oddi, S.; Maccarrone, M. Anandamide increases swelling and reduces calcium sensitivity of mitochondria. Biochem. Biophys. Res. Commun. 2009, 388, 439-442. [CrossRef] [PubMed]

59. Vequi-Suplicy, C.C.; Lamy, M.T.; Marquezin, C.A. The New Fluorescent Membrane Probe Ahba: A Comparative Study with the Largely Used Laurdan. J. Fluoresc. 2013, 23, 479-486. [CrossRef]

60. Colell, A.; García-Ruiz, C.; Lluis, J.M.; Coll, O.; Mari, M.; Fernández-Checa, J.C. Cholesterol Impairs the Adenine Nucleotide Translocator-mediated Mitochondrial Permeability Transition through Altered Membrane Fluidity. J. Biol. Chem. 2003, 278, 33928-33935. [CrossRef] [PubMed]

61. Senault, C.; Yazbeck, J.; Goubern, M.; Portet, R.; Vincent, M.; Gallay, J. Relation between membrane phospholipid composition, fluidity and function in mitochondria of rat brown adipose tissue. Effect of thermal adaptation and essential fatty acid deficiency. Biochim. Biophys. Acta (BBA) Biomembr. 1990, 1023, 283-289. [CrossRef]

62. Maccarrone, M.; Bellincampi, L.; Melino, G.; Agro, A.F. Cholesterol, but not its esters, triggers programmed cell death in human erythroleukemia K562 cells. JBIC J. Biol. Inorg. Chem. 1998, 253, 107-113. [CrossRef]

63. Solsona-Vilarrasa, E.; Fucho, R.; Torres, S.; Núñez, S.T.; Lámbarri, N.N.; Enrich, C.; García-Ruiz, C.; Fernández-Checa, J.C. Cholesterol enrichment in liver mitochondria impairs oxidative phosphorylation and disrupts the assembly of respiratory supercomplexes. Redox Biol. 2019, 24, 101214. [CrossRef] [PubMed]

64. Cantor, R.S. Lipid Composition and the Lateral Pressure Profile in Bilayers. Biophys. J. 1999, 76, 2625-2639. [CrossRef] 